\title{
ПIШВАНОВА ТАМАРА,
}

історик, член Начіональної спілки журналістів України, завідувач музейного фонду Донецького академічного українського музично-драматичного театру (до 2014 р.)

\section{МАТЕРІАЛИ ДО ІСТОРІЇ ПЕРШОГО УКРАЇНСЬКОГО ТЕАТРУ ДОНБАСУ - ВСЕДОНБАСІВСЬКОГО ДЕРЖАВНОГО УКРАЇНСЬКОГО ДРАМАТИЧНОГО ТЕАТРУ "ДОНДЕРЖДРАМА"}

\author{
У статті подані сторінки історії першого українського театру Донбасу - Вседонбасівсько- \\ го державного українського драматичного театру (Дондерждрами). Простежено етапи його \\ формування й діяльності від виникнення в 1928 році до 1935 року, коли театр перестав \\ існувати, злившись із пересувним українським театром імені Артема, який базувався в \\ Артемівську.
}

Ключові слова: Донбас; український драматичний театр; історія.

Постановка проблеми та стан її вивчення. Двадцяті роки XX сторіччя були часом національного відродження та розвитку української культури. Після знищення УНР саме в галузі культури багато митців знайшли альтернативний спосіб вираження національної самобутності свого народу. На хвилі політики українізації та коренізації виникає багато театрів, зокрема й на Східній Україні, на Донбасі. Їхня історія тривалий час узагалі не була об'єктом досліджень. Сьогодні ж актуальність накопичення первинної інформації з історії цього краю, їі узагальнення, аналіз і забезпечення наукового обігу праць з огляду на війну 2014-2015 рр. мають особливу актуальність.

Історія першого українського театру Донбасу - Вседонбасівського державного українського драматичного театру (Дондерждрами), як і явища українського театру на Донбасі взагалі, практично не досліджувалася. Дані про нього фрагментарні й викладені ще у XX ст. головним чином із позицій радянської історичної науки [1-2] та журналістики [5-8]. Наша апробаційна робота в "Донецькому віснику НТШ" [9] і ця стаття - практично перші спроби аналізу й переосмислення в нову епоху, епоху незалежної України, історії українського театру на Донбасі.

Мета статті - аналіз і введення в науковий обіг матеріалів до історії першого українського театру Донбасу Вседонбасівського державного українського драматичного театру (Дондерждрами).

Виклад основного матеріалу. На 1926-1934 роки припадає виникнення переважної більшості драматичних колективів професійного сценічного мистецтва України. У першу чергу це було пов'язане з підведенням підсумків перших двох років українізації в резолюції квітневого Пленуму ЦК КП(б)У від 20 травня 1925 року. У документі визнавалося, що культурне українське будівництво обслуговується недостатньою кількістю комуністичних сил, а тому воно живиться літературою "української інтелігенції з ідеологічно ворожим комунізму науково-історичним багажем". Політична боротьба в галузі культурного будівництва була дуже гострою, оскільки національна інтелігенція, безперечно, впливала на культурний процес в Україні. Мета була одна "посилювати комуністичний вплив в усьому культурно- му житті", "підтримувати розвиток української культури, національної за її мовою, формою і матеріалом і пролетарською за її суттю". Тому Радянська держава почала активно втручатися в ці роки в саму організацію театрального життя республіки. Так, у сезоні 1925-26 року в Україні було ліквідовано приватну антрепризу й створено мережу державних українських і російських театрів, українських академічних театрів опери та балету в Харкові, Одесі, Києві, безпосередньо підпорядкованих Відділу мистецтв Управління політосвіти НКО УРСР. Усього їх налічувалося десять.

У травні 1927 року була скликана спеціальна нарада при Агітпропвідділі ЦК ВКП(б), яка визначила подальший розвиток національних театрів країни, у тому числі й українських. Після наради приймається чергова партійна постанова більшовиків України - "Політика партії в справі української художньої літератури". У резолюції Х з'їзду КП(б)У від 29 листопада 1927 року відзначалося, що серед усіх театрів України тільки 26 \% складали українські, але "організація українського державного театру і опери становить нове художнє досягнення, дає можливість створення нової української драми і української опери, співзвучної всьому процесові соціалістичного будівництва".

У 1928 році урядом УРСР було ухвалено постанову "Про державні театри та їх об'єднання". Згідно із цією постановою, державними театрами вважалися ті сценічні колективи, які були безпосередньо підпорядковані Народному комісаріату освіти або окружним виконавчим комітетам і працювали за відповідними плановими завданнями, що їх затверджували Народний комісаріат освіти або окружні виконавчі комітети. Далі в постанові зазначалося, що в безпосередньому віданні Народного комісаріату освіти знаходяться державні театри, які завдяки своїй художній та ідеологічній цінності мають загальнореспубліканське значення. У сезоні 1928-29 року в Україні було вже 13 державних театрів, із них - чотири оперні і дев'ять драматичних (сім українських, один російський та один єврейський).

На кінець 1929 року в Україні, за даними НКО УРСР, нараховувалось 78 видовищних закладів, із них 35 українських. Державних з усієї кількості видовищних установ було 38, решта - трудові колективи. 
Саме у 1928 році на Донеччині, в колишній Сталінській окрузі, виникає Вседонбасівський державний український драматичний театр, який увійшов в історію культури Донеччини під скороченою назвою - Дондерждрама. Коротка історія Дондерждрами цікава тим, що частина її акторів у 40-50-х роках XX ст. складе театральну славу Донбасу, отримавши звання заслужених артистів України: П. Польова, Л. Усатенко, І. Авдієнко, М. Адамська.

Ряд дослідників історії театрального життя Донбасу 20-30-х років XX століття (Н. С. Кравцова [3], О. В. Новиченко [4] та ін.) уважають, що коріння історії Дондерждрами слід шукати в 1923 році, коли театр імені І. Франка з гастролями проїхав містами Донбасу. Так, дослідниця Н. Кравцова відзначає, що більше місяця трупа виступала в Юзівці, Артемівську, Слов'янську та інших містах при повних зборах, викликаючи захоплення мас. На прохання робітників група акторів із театру ім. Франка відкрила в Артемівську свою філію, що дістала назву Дондерждрама. Керував діяльністю філії режисер О. Юра-Юрський, серед акторського складу тут виступали відомі актори Ф. Барвинська та П. Нятко. Свою роботу в Донбасі фрілія розпочала постановкою п'єси М. Куліша "97". Окрім цієї п'єси, до репертуару Дондерждрами входили "Комуна в степах" М. Куліша, "Полум'яри" А. Луначарського, "Ревізор" М. Гоголя, "Фуенте Овехуна" Лопе де Веги. Театр був пересувним й обслуговував ще й сусідні райони [3].

Відзначимо, що обидві дослідниці використовували в якості джерела інформації другий том академічного видання "Український драматичний театр" АН УРСР (1959). Гортаючи сторінки газети "Кочегарка" за 1925 рік, ми знайшли дві рецензії на вистави, показані робітничому глядачу Донбасу. Так, газета "Кочегарка" від 13 жовтня 1925 року відзначала, що п'єсою "Дев'яносто сім" відкрились гастролі донфілії Державного театру імені Франка. Мусія Копистку грав Гнат Юра. В інших ролях були зайняті актори Маяк, Юрський, Семдор, Гаєвський, Братерський, Маякова, Слуцька [6].

13 жовтня 1925 року філія показувала виставу "Полум'яри" А. Луначарського, 14 жовтня - виставу "Гріх" за В. Винниченком у постановці Симона Семдора. 14 жовтня 1925 року на шпальтах газети "Кочегарка" з'явилась рецензія на виставу "Ревізор" [7]. Із рецензії ми дізнаємося, що вистава не вдалася, оскільки фрранківці намагалися показати сатиричну комедію як гротесковий водевіль. Більшість виконавців у виставі - студійці. У ролях були зайняти артисти Терниченко (Хлестаков), Семдор (Городничий), Маяк (Йосип), Юрський (Добчинський), Хоменко (Бобчинський), Федорович (почтмейстер), Горська (Ганна Андріївна), Скрипченко (Марія Антонівна). Таким чином, безпосередньо по гарячих слідах критик пише не про Дондерждраму, а про донецьку фрілію державного театру імені І. Франка, створену спеціально для обслуговування Донбасу.

ще в 1969 році дослідниця Надія Демидчук звернула увагу на цю обставину, ставлячи у своїй статті питання: "Чи справді фрілія театру імені Франка і була Дондерждрамою?" [5]. Помилка вищезгаданих дослідників була пов'язана з таким фактом: другий сезон Дондерждрама починала в дуже скрутному становищі: у театрі не було завідувача художньої частини, адміністратора, чіткого репертуарного плану. Тоді колектив театру звернувся до давнього друга Донбасу - театру імені І. Франка, який надав неоціненну допомогу, а не створював своєї фрілії під такою назвою. Завдяки ретельним пошукам дослідниці було встановлено, що в Сталіно під ору- дою Д. І. Шклярського наприкінці 1928 року почав свою роботу український театр, який, спираючись на спогади старих акторів, дослідниця називає першим стаціонарним.

Проглянувши документи Державного архіву Донецької області з метою знайти згадки про утворення театру, ми з'ясували: у 1927 році відбулася нарада культпрацівників Сталінського округу, на якій обговорювалося питання про створення пересувного театру в Сталінському окрузі. У 1928 році відбулося засідання президії райкому ВСРМ, на якому було продовжено обговорення про необхідність організації українського пересувного театру в Сталінському окрузі. 18 березня 1928 року Сталінський райком металістів обговорював проект організації та надання 6 тис. карбованців для організації пересувного українського театру в Сталінському окрузі (до речі, бюджет десяти державних театрів республіканського значення в 1927-28 p. сягав 1815600 крб, у1928-29 р. він збільшився до 2551332 крб).

4 травня 1928 року на засіданні правління Сталінського окружного відділення профспілки РАБІС знову обговорюється питання про організацію постійного пересувного театру для обслуговування робітничого району. Сталінська окружна профррада має протоколи, листи, проект резолюції, довідку та кошторис щодо організації та роботи Сталінського українського робітничого пересувного драматичного театру, його склад, репертуар та надання коштів на його утримання.

Отже, прямих документів щодо утворення Дондерждрами як першого українського постійного стаціонарного театру поки що не знайдено. Перша ж згадка про утворення постійного стаціонарного театру в місті Сталіно відноситься до 1932-1933 років і пов'язана зі Сталінським державним українським драматичним театром. Це постанова Сталінської міськради від 1932 року та протокол засідання Сталінської міськради від 29 серпня 1933 року про роботу Сталінського державного драматичного театру. Але театр виникає й починає працювати. Очолив Дондерждраму режисер Д. І. Шклярський. 20 жовтня 1928 року театр показав свою першу виставу "Рейки гудуть" В. Кіршона.

Другий сезон відкривався виставою "Кадри" І. Микитенка. Про подальші прем'єрні вистави при відкритті сезонів інформації поки що немає. Творча група складалася з таких акторів, як П. Польова, Р. Раїсова, П. Шевченко, Л. Усатенко, Д. І. Жуков, Є. Хуторна, Д. Гайдамака, І. Авдієнко, Н. Рейська, Ю. Шостаківська, О. Горська, л. Задніпровський, Н. Білодідова, режисерами були Терентьєв, Д. Шклярський, Є. Шнейдерман та інші.

У 1931 році 15-річною дівчиною розпочала свою творчу кар'єру майбутня заслужена артистка України Марія Адамська, яку запросив на роботу режисер Леонід Іванович Кліщеєв.

Репертуар театру складали п'єси "Кадри" І. Микитенка, "Рейки гудуть" Кіршона, "Яблуневий полон" Дніпровського, "Мина Мазало" Куліша. "Перша кінна", "Шахта "Марія", "Вулиця моєї радості", "Загибель ескадри", "Мій друг" та інші.

Газета "Молодой рабочий" уважно стежить за виставами Дондерждрами першого року їі існування. Так, подією першого сезону стала постановка п'єси М. Куліша "Мина Мазайло" режисером Терентьєвим, якому "вдалося розв'язати ії як гостру сатиру й довести, що колектив театру здатний брати до репертуару глибокі, цікаві твори сучасних українських драматургів".

Робота театру тривала в дуже складних умовах. "По- 
трібно відзначити, і це не буде перебільшенням, що працює театр тільки завдяки героїчним зусиллям всього колективу", - визнає газета "Диктатура труда" вже в грудні 1928 р. Підбиваючи підсумки сезону, газети зазначали, що "на першому році існування не було як слід організовано його [театру] бюджетні справи... Але тепер, після першого року існування, виріс у міцний колектив вседонбасівського значення" [1].

Дослідниця Надія Демидчук відзначає: "У колективу не було пристойного приміщення. Часті переїзди 3 шахти на шахту з усім майном, дітьми, на підводах, життя табором по клубах - усе це, безумовно, не сприяло тому, щоб актори затримувались у Сталінській держдрамі. А це серйозно позначалось на якості вистав, на роботі колективу. Цілком праві були критики, коли стверджували, що робота на Донбасі вимагає від театру великого героїзму" [5].

Слід Дондерждрами губився на початку 30-х років XX століття. Дивом збереглися кілька фотографій, за якими можна встановити поточний репертуар театру: "Дівчата нашої країни" І. Микитенка (1932р.); "Чужа дитина" В. Шкваркіна (1933 р.); "Вулиця радості" Н. А. Зархі (1934р.); "Гейша" (за мотивами п'єси Давида Беласко та повісті Джона Лютера Лонга "Гейша") (1934р.). На звороті останніх двох світлин надпис: "Донбас. Парткомуна".

Дослідниці Н. Демидчук удалося встановити, що в 1933 році театр виїхав на гастролі по Донбасу, півдню України, Молдавії. Повернувся театр на Донбас на початку 1934 року, деякий час актори працювали в Слов'янську, Артемівську, Горлівці, Краматорську. Їй удалося також знайти оголошення про урочистий ювілей Юлії Степанівни Шостаківської та Дмитра Абрамовича Гайдамаки, що його 20 лютого 1934 року готується відсвяткувати в Слов'янську Вседонбасівський державний український драматичний театр. І дати: 1928-1934 рр., що підтверджувало дату заснування театру й те, що в 1934 році театр ще працював у Слов'янську [Там само].

Остання згадка про Дондерждраму відноситься до 1935 року. Подія пов'язана з реорганізацією двох театрів - Дондержрами й театру імені Артема (який виник у 1929 році в Артемівському окрузі) в один театральний колектив: Вседонецький український драматичний театр імені Артема. Надія Демидчук помилково вказує 1934 рік як рік реорганізації Дондерждрами. $€$ непрямі документи, які свідчать про 1935 рік: газета "Социалистический Донбасс" [8] та особовий листок з обліку кадрів актриси театру імені Артема Дар'ї Федорівни Антонової (1905-?), заповнений нею в 1950 році. Так, газета повідомляє, що обидва театри до свого злиття в 1935 році обслугували більше 6 млн глядачів. В особовому листку актриса чітко вказує свій творчий шлях: 1926-1930рр. - театр імені І. Франка (Київ), 1930 (переводом) - Вседондерждрама (Сталіно), 1935 - театр імені Артема (злиття двох театрів, Артемівськ, Сталіно. Донбас) [9].

Таким чином, можна зробити такі висновки:

1. Дондерждрама $€$ першим самостійним українським театром на Донбасі, який виникає в 1928 році, і не $€$ фрілією театру імені Франка.

2. Поки що не знайдені архівні документи про утворення Дондерждрами як першого українського стаціонарного театру Донбасу.

3. Театр базується в місті Сталіно, не маючи постійного театрального приміщення. Великою проблемою були також відсутність коштів та чіткого репертуарного плану, плинність акторських кадрів. Згадки про роботу в місті Сталіно відносяться лише до 1928 та1929 років.

4. У 1930-1934 рр. театр працював за межами міста Сталіно, гастролюючи по містах області та України.

5. У 1935 році театр перестав існувати, злившись із пересувним українським театром імені Артема, який базувався в Артемівську.

\section{ЛІТЕРАТУРА}

1. Культурне будівництво в Українській РСР. Найважливіші рішення Комуністичної партії і Радянського уряду. 1917-1959 рр. : зб. документів у 2-х тт. / [ред. О. І. Євсєєв]. К. : Державне вид-во політичної літ-ри УРСР, 1960. - Т. 1 (1917 - червень 1941 рр.). - 882 с.

2. Барабаш Л. І. Українська драматургія і театр на Донеччині 20-х років: аспекти побутування і розвитку / Л. І. Барабаш // Здійснення ленінської національної політики на Донбасі : тези доп. і повідомлень респ. наук. конф. (Донецьк, 21-24 лютого1990 р.). - Донецьк, 1990. - С. 95-96.

3. Кравцова Н. С. Становлення професійного театру Донбасу в 20-ті рр. XX ст. / Н. С. Кравцова // Історичні і політологічні дослідження. - 2002. - № 1 (9). - С. 107.

4. Новиченко О. В. Театральная жизнь Донбасса 20-30-х годов XX века / О. В. Новиченко // Літопис Донбасу: Краєзнавчий збірник. - Донецьк : Літопис, 2007. - Вип. 15. - С. 97.

5. Демидчук Н. Розглядаючи стару фотографію / Н. Демидчук // Донбас. - 1969. - № 3. - С. 88-97.

6. Треплев К. Гастроли донфилии театра имени И. Франко "Девяносто семь" - Николая Кулиша / К. Треплев // Кочегарка. - 1925. - 13 октября.

7. К. Т. Гастроли донфилии державного театра им. И. Франко. "Ревизор" Гоголя / К. Т. // Кочегарка. - 1925. - 14 октября.

8. Театр імені Артема // Социалистический Донбасс. 1936. - 17 октября.

9. Пішванова Т. Вседонбасівський державний український драматичний театр (Дондерждрама): сторінки історії / Т. Пішванова // Донецький вісник Наукового товариства ім. Шевченка. - Т. 37. - Донецьк : Український культурологічний центр, Східний видавничий дім, 2013. - С. 113-121.

\section{Пишванова Тамара,}

историк, член Наџионального союза журналистов Украины, заведующая музейным фондом

Донеикого академического украинского музыкально-драматического театра (до 2014 г.)

\section{МАТЕРИАЛЫ К ИСТОРИИ ПЕРВОГО УКРАИНСКОГО ТЕАТРА ДОНБАССА - ВСЕДОНБАССКОГО ГОСУДАРСТВЕННОГО УКРАИНСКОГО ДРАМАТИЧЕСКОГО ТЕАТРА "ДОНДЕРЖДРАМА"}

В статье представлены страницы истории первого украинского театра Донбасса - Вседонбасского государственного украинского драматического театра (Донгосдрамы). Прослежено этапы его формирования и деятельности от возникновения в 1928 году до 1935 года, когда театр перестал существовать, слившись с передвижным украинским театром имени Артема, основанным в Артемовске.

Ключевые слова: Донбасс; украинский драматический театр; история. 
Pishvanova Tamara,

Historian, Member of the National Union of Journalists of Ukraine,

Manager of Museum Reserves of Donetsk Academic Ukrainian Music and Drama Theater (up to 2014)

\section{BACKGROUND MATERIALS ABOUT THE FIRST UKRAINIAN THEATER OF THE DONBAS - THE ALL-DONBAS STATE UKRAINIAN DRAMA THEATER "DONDERZHDRAMA"}

The paper presents some pages of history of the First Ukrainian Theater of The Donbas - The All-Donbas State Ukrainian Drama Theater "Donderzhdrama". It covers its setting-up and operation milestones from the foundation in 1928 to 1935 when the Theater ceased to exist while merging with Artem Ukrainian Mobile Theater, based in Artemivsk.

The author draws a conclusion that Donderzhdrama is the first independent Ukrainian theater in the Donbas rather than a branch of Franko Theater. From its foundation in 1928 the Theater was based in the city of Stalino, having no permanent premises. It also faced such great problems as lack of funds and a clean-cut repertory plan as well as actors' turnover. Recollections about the operation in Stalino date back to only 1928 and 1929. In 1930 1934 the Theater performed outside Stalino, touring cities of the region and Ukraine. It is acknowledged that there are no archive documents regarding the setting up of Donderzhdrama as the first Ukrainian stationary theater of the Donbas. The Donderzhdrama staff comprised such actors as P. Poliova, R. Raisova, P. Shenchenko, L. Usatenko, D.I. Zhukov, Y. Khutorna, D. Gaidamaka, I. Avdienko, N. Reiska, Y. Shostakivska, O. Gorska, L. Zadniprovskyi, N. Bilodidova, stage directors Tetentiev, D. Shkliarskyi, Y. Shneiderman et al. In 1928 Donderzhdrama was headed by Stage Director D.I. Shkliarskyi. In 1931 Maria Adamska, a future Distinguished Artist of Ukraine, who was 15 at the time, embarked upon her creative career at the Theater. The Theater repertory included such plays as I. Mykytenko's "Personnel", Kirshon's "Humming Rails", Dniprovskyi's "Apple Captivity", Kulish's "Myna Mazalo", "First Horse Army", "Mine "Maria", "Street of My Joy", "Squadron Ruin", "My Friend" and others.

Key words: Donbas; Ukrainian Drama Theater; history.

\section{REFERENCES}

1. Yevseiev O. I., ed. (1960), Cultural construction in the Ukrainian SSR. The most important decision of the Communist Party and the Soviet government. 1917-1959 biennium.: Coll. documents in 2 vols., Kyiv, Vol. 1 (1917 - June 1941), 882 p. (ukr).

2. Barabash L. I. (1990), Ukrainian dramaturgy and Theatre in Donetsk region in the 1920s: Aspects of existence and development, in Implementation Leninist national policy in Donbas, abstracts and reports of the Republican sciences. Conf., Donetsk, pp. 95-96 (ukr).

3. Kravtsova N. (2002), Formation of professional theater in Donbass 20th-ies XX century, Istorychni i politolohichni doslidzhenia, № 1 (9), p. 107 (ukr)

4. Novichenko O. V. (2007, Litopys Donbasu: Kraieznavchyi zbirnyk, Donetsk, issue 15, p. 97 (ukr).

5. Demydchuk N. (1969), Donbas, № 3, pp. 88-97 (ukr).

6. Treplev K. (1925), Kochegarka, October 13 (rus).

7. K. T. (1925), Kochegarka, October 14 (rus).

8. Sotsialisticheskiy Donbass (1936), October 17 (rus).

9. Pishvanova T. (2013), The All-Donbass State Ukrainian Drama Theater (Donderzhdrama): pages of history, in Donetsk Journal of Scientific Society. Shevchenko, Vol. 37, Ukrainian Cultural Centre, East Publishing House, Donetsk, pp. 113-121 (ukr).

(C) Пішванова Тамара

Надійшла до редакції 16.02.2015 